\title{
Environmental Contaminations and Occupational Exposures Involved in Preparation of Chemotherapeutic Drugs
}

\author{
Shinichiro Maeda ${ }^{1,2}$, Masako Oishi ${ }^{1}$, \\ Yoshihiro Miwa ${ }^{1}$ and Nobuo Kurokawa ${ }^{1}$ \\ ${ }^{1}$ Department of Pharmacy, Osaka University Hospital \\ ${ }^{2}$ Graduate School of Pharmaceutical Sciences, Osaka University
}

Japan

\section{Indroduction}

Many healthcare workers are concerned about the risk of occupational exposures to hazardous drugs. Since Falck [Falck et al.,1979] reported that mutagens were detected in the urine samples of nurses involved in chemotherapy, many reports have been published about the presence of urinary mutagen [Roth et al.,1994; Burgaz et al.,1999; Kasuba et al.,1999; Lanza et al.,1999; Jakab et al.,2001; Kopjar \& Garaj-Vrhovac,2001], and about the detection of unchanged hazardous drugs in the urine samples of healthcare workers [Hirst et al.,1984; Sessink et al.,1992, 1994, 1995; Ensslin et al.,1994; Minoia et al.,1998; Burgaz et al.,1999; Pethran et al.,2003]. Tomioka [Tomioka \& Kumagai,2005] monitored occupational exposures to hazardous drugs by routes of exposures and the levels at which the drugs exert their effects; i.e. (i) external exposures, exposure to airborne drugs and drugs deposited on the working table; (ii) internal exposures, presence of drugs or their metabolites in blood and urine; (iii) cellular level effects, presence of mutagens in urine and frequency of sister chromatid exchanges; and (iv) effects on individual level, susceptibility to cancer and effects on reproduction. Recent improvements of analytical instruments have permitted direct monitoring of external exposures and internal exposures.

Hospital pharmacists in Japan have been required to prepare chemotherapeutic drugs. The Japanese Society of Hospital Pharmacists (JSHP) revised the "Guideline for the Handling of Antineoplastic Drugs in Hospitals" in 2005, and recommended standard precautionary measures for using the laminar flow cabinet, masks, gloves, caps, disposable nonwoven clothes, and luer-lok syringes. This guideline was based on the "NIOSH alert" by the National Institute for Occupational Safety and Health [NIOSH,2004]. In addition, the JSHP investigated occupational exposures to cyclophosphamide in several hospitals, and reported that internal exposures and external exposures varied greatly in individuals, in hospitals and even in countries. This investigation led to increased concerns among hospital pharmacists about the exposures to chemotherapeutic drugs.

Before the JSHP investigation, we have investigated whether the precautionary measures we took were adequate to prevent occupational exposures [Ikeda et al.,2007; Maeda et al.,2010]. We focused on occupational exposures to epirubicin, cyclophosphamide and ifosfamide, 
and reported that the surfaces of biological safety cabinets (BSCs) and ambient environments were contaminated by these drugs during preparation by pharmacists (external exposures). However, detection frequencies and amounts of these drugs were low levels, compared with previous reports in Japan [Nabeshima et al.,2008; Yoshida et al.,2009]. In addition, no drugs were detected in sera and urine samples of healthcare workers involved in chemotherapy (internal exposures). Thus, we concluded that adequate precautionary measures and improved awareness regarding handling of chemotherapeutic drugs could reduce the risk of occupational exposures. These investigations were focused on specific drugs, however, a progress of chemotherapy increases amounts of and varieties of chemotherapeutic drug uses. Thus, more versatile methods are desired.

Multicomponent analyses are useful for monitoring environmental contaminations, such as pesticide chemicals [Lissalde et al.,2011; Miao et al.,2011] and air pollution [Skoczynska et al.,2008; Sebok et al.,2009]. However, there are only several reports in the fields of occupational exposures to healthcare workers [Larson et al.,2003; Sabatini et al.,2005; Sottani et al.,2007, 2008; Nussbaumer et al.,2010].

In this paper, we used liquid chromatography-mass spectrometry/mass spectrometry (LCMS/MS) and developed multicomponent analysis procedures for chemotherapeutic drugs, and assessed the levels of environmental contaminations involved in preparation of chemotherapeutic drugs. We selected ten kinds of drugs mainly used in chemotherapy; cyclophosphamide, ifosfamide, epirubicin, doxorubicin, vindesine, vincristine, vinblastine, irinotecan, docetaxel and paclitaxel. Classification of drugs, chemical natures, regulations, uses of drugs, side effects, carcinogenicities, cytotoxicities [Goolsby \& Lombardo,2006] and pregnancy categories of each drug were summarized in Table 1.

\begin{tabular}{|c|c|c|c|c|}
\hline No. & Name of drugs & Regulations & $\begin{array}{l}\text { Classification of drugs } \\
\text { (chemical natures) }\end{array}$ & Main uses of drugs \\
\hline 1 & Vindesine & $\begin{array}{l}\text { Powerful } \\
\text { drug }\end{array}$ & $\begin{array}{c}\text { Vincalkaloid } \\
\text { (antimicrotuble drug) }\end{array}$ & Leulemia, Lung cancer \\
\hline 2 & Vincristine & $\begin{array}{l}\text { Powerful } \\
\text { drug }\end{array}$ & $\begin{array}{c}\text { Vincalkaloid } \\
\text { (antimicrotuble drug) }\end{array}$ & $\begin{array}{c}\text { Leukemia, Malignant lymphoma, } \\
\text { Multiple myeloma }\end{array}$ \\
\hline 3 & Vinblastine & $\begin{array}{l}\text { Powerful } \\
\text { drug }\end{array}$ & $\begin{array}{l}\text { Vincalkaloid } \\
\text { (antimicrotuble drug) }\end{array}$ & $\begin{array}{l}\text { Malignant lymphoma, Urothelial } \\
\text { carcinome }\end{array}$ \\
\hline 4 & Doxorubicin & $\begin{array}{l}\text { Powerful } \\
\text { drug }\end{array}$ & $\begin{array}{c}\text { Anthracycline } \\
\text { (anticancerous antibiotic) }\end{array}$ & $\begin{array}{l}\text { Malignant lymphoma, Breast } \\
\text { cancer, Lung cancer }\end{array}$ \\
\hline 5 & Epirubicin & $\begin{array}{l}\text { Powerful } \\
\text { drug }\end{array}$ & $\begin{array}{c}\text { Anthracycline } \\
\text { (anticancerous antibiotic) }\end{array}$ & $\begin{array}{l}\text { Leukemia, Malignant lymphoma, } \\
\text { Breast cancer }\end{array}$ \\
\hline 6 & Ifosfamide & $\begin{array}{l}\text { Powerful } \\
\text { drug }\end{array}$ & Mustard (alkylating drug) & Lung cancer, Prostatic cancer \\
\hline 7 & Cyclophosphamide & $\begin{array}{l}\text { Powerful } \\
\text { drug }\end{array}$ & Mustard (alkylating drug) & $\begin{array}{l}\text { Leukemia, Breast cancer, } \\
\text { Rheumatism }\end{array}$ \\
\hline 8 & Irinotecan & $\begin{array}{l}\text { Powerful } \\
\text { drug }\end{array}$ & Topoisomerase I inhibitor & $\begin{array}{l}\text { Lung cancer, Ovarian cancer, } \\
\text { Colorectal cancer }\end{array}$ \\
\hline 9 & Docetaxel & Toxicant & $\begin{array}{c}\text { Taxane } \\
\text { (antimicrotuble drug) }\end{array}$ & $\begin{array}{c}\text { Breast cancer, Lung cancer, } \\
\text { Uterine cancer }\end{array}$ \\
\hline 10 & Paclitaxel & Toxicant & $\begin{array}{c}\text { Taxane } \\
\text { (antimicrotuble drug) }\end{array}$ & $\begin{array}{l}\text { Breast cancer, Lung cancer, } \\
\text { Uterine cancer }\end{array}$ \\
\hline
\end{tabular}




\begin{tabular}{|c|c|c|c|c|c|}
\hline \multirow{2}{*}{ No. } & \multirow{2}{*}{ Name of drugs } & \multirow{2}{*}{ Main side effects } & \multicolumn{2}{|c|}{ Hazard potential } & \multirow[b]{2}{*}{ Pregnancy } \\
\hline & & & Carcinogenicity & Cytotoxicity & \\
\hline 1 & Vindesine & Myelosuppression & & Vesicant & \\
\hline 2 & Vincristine & $\begin{array}{l}\text { Peripheral neuropathy, } \\
\text { Cardiotoxicity }\end{array}$ & & Vesicant & Category D \\
\hline 3 & Vinblastine & Myelosuppression & & Vesicant & Category D \\
\hline 4 & Doxorubicin & $\begin{array}{l}\text { Delayed myelosuppression } \\
\text { and cardiotoxicity }\end{array}$ & $\begin{array}{l}\text { Probably } \\
\text { carcinogenic }\end{array}$ & Vesicant & Category D \\
\hline 5 & Epirubicin & $\begin{array}{l}\text { Delayed myelosuppression } \\
\text { and cardiotoxicity }\end{array}$ & & Vesicant & Category D \\
\hline 6 & Ifosfamide & Hemorrhagic cystitis & & Irritant & Category D \\
\hline 7 & Cyclophosphamide & $\begin{array}{l}\text { Myelosuppression, } \\
\text { Hemorrhagic cystitis }\end{array}$ & Carcinogenic & Irritant & Category D \\
\hline 8 & Irinotecan & $\begin{array}{l}\text { Delayed diarrhea, } \\
\text { Myelosuppression }\end{array}$ & & $\begin{array}{c}\text { Non- } \\
\text { vesicant }\end{array}$ & Category D \\
\hline 9 & Docetaxel & $\begin{array}{l}\text { Myelosuppression, Pulmonary } \\
\text { fibrosis }\end{array}$ & & Vesicant & Category D \\
\hline 10 & Paclitaxel & $\begin{array}{l}\text { Myelosuppression, Perepheral } \\
\text { neuropathy }\end{array}$ & & Vesicant & Category D \\
\hline
\end{tabular}

Regulations, use of drugs and side effects were authorized by the Ministry of Health, Labour and Welfare in Japan.

Carcinogenicities were classified by IARC monographs on the evaluation of the carcinogenic risk of chemicals to humans.

Pregnancy categories were classified by U.S. Department of Health and Human Services Food and Drug Administration. Category D was "there is positive evidence of human fetal risk based on adverse reaction data from investigational or marketing experience or studies in humans, but potential benefits may warrant use of the drug in pfegnant women despite potential risks."

Table 1. Charactaristics of selected chemotherapeutic drugs.

\section{Materials and methods}

\subsection{Chemicals and materials}

Doxorubicin, ifosfamide, cyclophophamide and paclitaxel were purchased from Wako Pure Chemical (Osaka, Japan). 3,4-Anhydro vincristine [internal standard (IS) 1] was purchased from Toronto Research Chemicals (Toronto, Canada). Camptothecin (IS 2) was purchased from Tokyo Chemical Industry (Tokyo, Japan). Docetaxel, carminomycin (IS 3) and trofosfamide (IS 4) were purchased from Santa Cruz Biotechnology (California, USA). Irinotecan and cephalomannine (IS 5) were purchased from Sigma-Aldrich (Missouri, USA). Vincristine, vinblastine and epirubicin were kindly provided by Nippon Kayaku. Vindesine was kindly provided by Shionogi. Acetonitrile and methanol (LC-MS chromasolv) were also purchased from Sigma-Aldrich (Missouri, USA), and formic acid was purchased from Wako Pure Chemicals.

\subsection{Preparation of stock solutions, working solutions and calibration standards}

Vindesine was prepared in a solution of $0.1 \%$ formic acid-water to obtain a final concentration of $2 \mathrm{mg} / \mathrm{ml}$. Camptothecin was prepared in a solution of $0.1 \%$ formic acidmethanol to obtain a final concentration of $100 \mu \mathrm{g} / \mathrm{ml}$. Other drugs were prepared in a 
solution of $0.1 \%$ formic acid-methanol to obtain a final concentration of $2 \mathrm{mg} / \mathrm{ml}$. Aliquots of these solutions were stored at $-80^{\circ} \mathrm{C}$, then diluted in $0.1 \%$ formic acid-methanol to obtain a final concentration of $100 \mu \mathrm{g} / \mathrm{ml}$ each stock solution and stored at $-30^{\circ} \mathrm{C}$.

Stock solutions of three vincalkaloids were mixed to working solutions, containing 33.3 $\mu \mathrm{g} / \mathrm{ml}$ of vindesine, vincristine and vinblastine, respectively. Stock solutions of other seven drugs were also mixed and diluted in $0.1 \%$ formic acid-methanol to working solutions, containing $5 \mu \mathrm{g} / \mathrm{ml}$ of doxorubicin, epirubicin, ifosfamide, cyclophosphamide, irinotecan, docetaxel and paclitaxel, respectively. The working solutions of internal standard mixtures were prepared by containing $100 \mu \mathrm{g} / \mathrm{ml}$ of 3,4-anhydro vincrisitine, and containing 10 $\mu \mathrm{g} / \mathrm{ml}$ of carminomycin, trofosfamide, camptothecin and cephalomannine, respectively. These working solutions were also stored at $-30^{\circ} \mathrm{C}$. We used black Eppendorf tubes for stock solutions of anthracycline drugs and vincalkaloid drugs, and for all working solutions. The calibration standards were prepared by diluting these working solutions.

\subsection{Chromatographic conditions}

An Alliance 2695 HPLC separation module (Waters; Massachusetts, USA) with PDA detector, cooled autosampler and column oven was used to perform this monitoring. Chromatographic separation was achieved on an octadecyl silyl column (Inertsil ${ }^{\circledR}$ ODS-3; 50 $\mathrm{mm} \times 2.1 \mathrm{~mm}$; particle size, $3 \mu \mathrm{m}$; GL Sciences, Tokyo, Japan) with a guard column (cartridge guard-column $\mathrm{E}^{\circledR} ; 20 \mathrm{~mm} \times 2.0 \mathrm{~mm}$; particle size, $3 \mu \mathrm{m}$, GL Sciences, Tokyo, Japan). Column oven was maintained at $30^{\circ} \mathrm{C}$ and autosampler was maintained at $5^{\circ} \mathrm{C}$. The mobile phases consisted of $0.1 \%$ formic acid-water (mobile phase A) and acetonitrile (mobile phase B). A flow rate was $0.3 \mathrm{ml} / \mathrm{min}$ and gradient elution was performed in the following manner: $15 \%$ of mobile phase B to $45 \%$ over $10 \mathrm{~min}$; $45 \%$ of mobile phase B to $80 \%$ over $7 \mathrm{~min}$. Subsequently, the concentration of mobile phase B was linearly decreased to $15 \%$ for $1 \mathrm{~min}$ and equilibrated for $4 \mathrm{~min}$. Total run time was $22 \mathrm{~min}$.

\subsection{Mass spectrometry conditions}

A tandem quadrupole MS TQD (Waters; Massachusetts, USA), operated in multiple reaction monitoring (MRM) in positive electrospray ionization (ESI) mode, was used for detection and MassLynx 4.1 software was used for data acquisition and processing. MS/MS parameters (precursor ion, product ion, cone energy, collision energy and retention time) of each drug were individually optimized by QuanOptimize software and syringe pump infusion in primary mobile phase by constant flow (Table 2).

\subsection{Precautionary measures and personals involved in preparation of chemotherapeutic drugs}

Precautionary measures were based on "NIOSH alert" [NIOSH,2004] and "Guidelines for the Handling of Antineoplastic Drugs in Hospitals" by JSHP (Table 3). A preparation area for outpatient chemotherapy was selected as an environmental monitoring. The numbers of person involved in preparation for outpatients were eight; six men and two women, and ages were from twenty-four to forty-one. We rotated schedules regularly, and limited successive preparation time to 1 hour. 


\begin{tabular}{|c|c|c|c|c|c|}
\hline Parameters & $\begin{array}{l}\text { Precersor } \\
\text { ion }\end{array}$ & $\begin{array}{l}\text { Product } \\
\text { ion }\end{array}$ & $\begin{array}{l}\text { Cone } \\
\text { energy }(\mathrm{V})\end{array}$ & $\begin{array}{l}\text { Collision } \\
\text { energy (V) }\end{array}$ & $\begin{array}{l}\text { Retention } \\
\text { time (min) }\end{array}$ \\
\hline \multicolumn{6}{|l|}{ Compounds } \\
\hline Vindesine & 754.5 & 124.2 & 55 & 50 & 1.65 \\
\hline Vincristine & 825.4 & 765.6 & 70 & 40 & 5.02 \\
\hline Vinblastine & 811.4 & 224.1 & 60 & 45 & 5.75 \\
\hline 3,4-Anhydro vincristine (IS 1) & 807.4 & 747.5 & 65 & 30 & 6.22 \\
\hline Doxorubicin & 544.5 & 397.2 & 20 & 12 & 6.18 \\
\hline Epirubicin & 544.5 & 397.2 & 20 & 12 & 6.60 \\
\hline Carminomycin (IS 2) & 514.2 & 307.2 & 20 & 25 & 8.29 \\
\hline Ifosfamide & 261.0 & 153.9 & 45 & 25 & 7.21 \\
\hline Cyclophosphamide & 261.0 & 140.3 & 45 & 30 & 7.63 \\
\hline Trofosfamide (IS 3) & 323.1 & 153.9 & 30 & 25 & 12.69 \\
\hline Irinotecan & 587.7 & 167.3 & 60 & 45 & 5.77 \\
\hline Camptothecin (IS 4) & 349.1 & 305.2 & 50 & 25 & 9.51 \\
\hline Docetaxel & 808.8 & 226.1 & 20 & 14 & 15.95 \\
\hline Paclitaxel & 854.8 & 286.3 & 25 & 24 & 16.48 \\
\hline Cephalomannine (IS 5) & 832.8 & 264.2 & 25 & 20 & 16.09 \\
\hline
\end{tabular}

Table 2. Parameters of MS/MS analysis.

\begin{tabular}{ll}
\hline No & \multicolumn{1}{c}{ Precautionary measures } \\
\hline 1 & $\begin{array}{l}\text { Prepare chemotherapeutic drugs in a centralized area restricted to authorized } \\
\text { personnel with expertise in the preparatory techniques and the characteristics of these } \\
\text { drugs. }\end{array}$ \\
2 & Prepare these drugs in a biological safety cabinet Class II Type B. \\
3 & Place a superabsorbent sheet on the surfaces of the preparation cabinets. \\
4 & Use syringes with Luer-Lok-type fittings for preparing these drugs. \\
5 & Use gowns made of a lint-free, low-permeability fabric. The gown should have a closed \\
front, long sleeves, and elastic or knit-closed cuffs. \\
6 & Use disposable nitrile rubbers gloves doubly, and change gloves every hour or on \\
& accidental exposures. \\
7 & Wear disposable mask and cap. \\
8 & Remove protective clothing carefully to avoid spreading contaminations. \\
9 & Maintain a negative pressure in the drug vials. \\
10 & Always close the cover of trash boxes used to dispose of these drugs. \\
\hline
\end{tabular}

These measures are based on the NIOSH alert, and we take measure No. 3 for additional precaution.

Table 3. Precautionary measures we took.

\subsection{Sampling procedures of ambient environment}

We collected wiping samples from the surfaces of the BSCs and from the surfaces of the tables inside a separated area and outside one (Fig. 1). Investigations were carried out as 
soon as daily preparation for outpatients had finished and before daily cleaning-up procedures, and obtained samples were immediately extracted and measured by LCMS/MS equipments. We took this monitoring on seven days for successive two weeks.
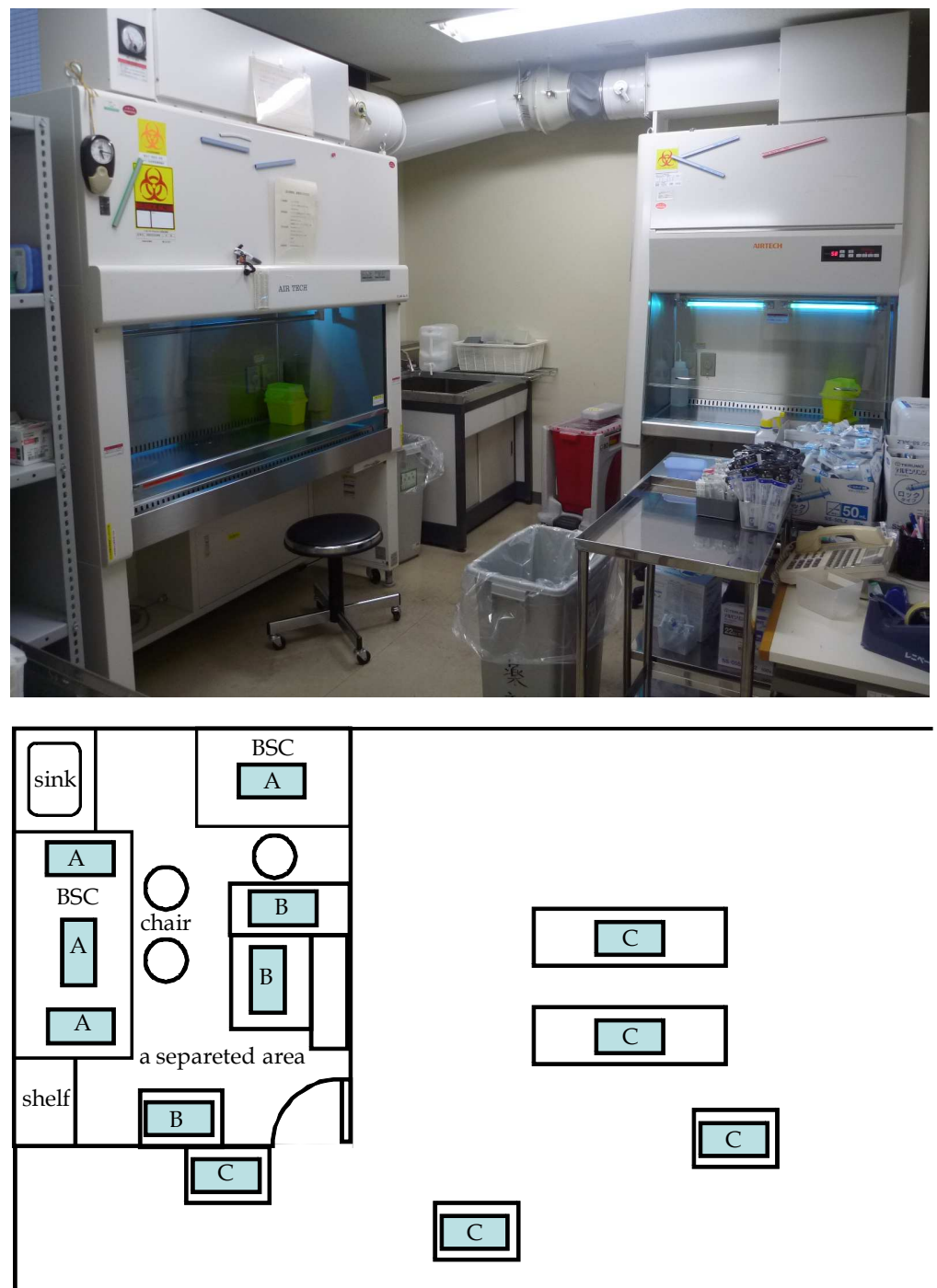

Fig. 1. Photograph of a preparation area (inside a separated area) for outpatients chemotherapy, and floor layout of a preparation area and sampling spots. A) Surfaces of the BSCs, B) Surfaces of the tables inside a separated area, C) Surfaces of the tables outside a separated area.

An extraction of wiping samples for environmental assessments was modified by our previous report [Maeda et al.,2010]. Briefly, we first applied internal standards mixtures, 
containing $10 \mu \mathrm{g}$ of 3,4-anhydro vincrisitine, $500 \mathrm{ng}$ of carminomycin, trofosfamide, camptothecin and cephalomannine to sampling spots. After these spots were air-dried, we wiped $800 \mathrm{~cm}^{2}$ area $(20 \mathrm{~cm} \times 40 \mathrm{~cm})$ with a sheet of Kimwipe ${ }^{\circledR}$ S-200 $(120 \mathrm{~mm} \times 215 \mathrm{~mm}$, Nippon Paper Crecia, Tokyo, Japan) wetted with $1 \mathrm{ml}$ of $0.1 \%$ formic acid- $70 \%$ methanol. We repeated wiping operation twice, then placed both sheets in light-blocking polypropylene conical tubes and added $8 \mathrm{ml}$ of $0.1 \%$ formic acid- $70 \%$ methanol. We shook these tubes for $30 \mathrm{~min}, 2,000$ rotations per min. Obtained extracts were directly injected into LC-MS/MS equipments without dilution.

\section{Results}

All drugs were clearly detected and quantified over a total run time of $22 \mathrm{~min}$. The calibration curves were fitted by the linear regression 5-1000 ng/wipe for doxorubicin, epirubicin, ifosfamide, cyclophosphamide, irinotecan and paclitaxel, 10-1000 ng/wipe for docetaxel, and 100-10000 ng/wipe for vindesine, vincristine and vinblastine, respectively.

Table 4 showed the positive ratio of detection and amounts of detected drugs. The surfaces of the BSCs were occasionally contaminated, meanwhile, contaminations in the surfaces of the tables inside a separated area and outside one were at low levels.

\begin{tabular}{|c|c|c|c|c|c|c|}
\hline \multirow[t]{2}{*}{ Sampling spots } & \multicolumn{2}{|c|}{$\begin{array}{l}\text { A) Surfaces } \\
\text { of the BSCs }\end{array}$} & \multicolumn{2}{|c|}{$\begin{array}{l}\text { B) Surfaces of the tables } \\
\text { inside a separated area }\end{array}$} & \multicolumn{2}{|c|}{$\begin{array}{l}\text { C) Surfaces of the } \\
\text { tables outside a } \\
\text { separated area }\end{array}$} \\
\hline & $\begin{array}{l}\text { Positive } \\
\text { samples } \\
(\mathrm{n}=28)\end{array}$ & $\begin{array}{l}\text { Amounts } \\
\text { (ng/wipe) }\end{array}$ & $\begin{array}{l}\text { Positive samples } \\
\qquad(\mathrm{n}=14)\end{array}$ & $\begin{array}{l}\text { Amounts } \\
\text { (ng/wipe) }\end{array}$ & $\begin{array}{l}\text { Positive } \\
\text { samples } \\
(\mathrm{n}=14)\end{array}$ & $\begin{array}{l}\text { Amounts } \\
\text { (ng/wipe) }\end{array}$ \\
\hline Vindesine & 0 & - & 0 & - & 0 & - \\
\hline Vincristine & 0 & - & 0 & - & 0 & - \\
\hline Vinblastine & 0 & - & 0 & - & 0 & - \\
\hline Doxorubicin & 5 & $7 \sim 114$ & 0 & - & 0 & - \\
\hline Epirubicin & 0 & - & 0 & - & 0 & - \\
\hline Ifosfamide & 0 & - & 1 & 7 & 0 & - \\
\hline Cyclophosphamide & 9 & $5 \sim 68$ & 1 & 21 & 1 & 7 \\
\hline Irinotecan & 0 & - & 0 & - & 0 & - \\
\hline Docetaxel & 3 & $9 \sim 348$ & 0 & - & 0 & - \\
\hline Paclitaxel & 1 & 19 & 1 & 14 & 0 & - \\
\hline
\end{tabular}

Table 4. Frequencies and amounts of drugs detected in wipe samples.

\section{Discussion}

Since Falck's report [Falck et al.,1979], many healthcare workers are concerned about the risk of occupational exposures to hazardous drugs. Previously, in studies of external 
exposures [Sessink et al.,1992; Minoia et al.,1998; Sabatini et al.,2005; Hedmer et al.,2008] and studies in internal exposures [Hirst et al.,1984; Sessink et al.,1992, 1994, 1995; Ensslin et al.,1994; Burgaz et al.,1999; Pethran et al.,2003], cyclophosphamide was frequently used as a marker of occupational exposures because of its slight volatility and human genotoxicity [Connor et al.,2000], reproductive toxicity [Anderson et al.,1995], carcinogenicity [IARC,1981], and ease of detection [Turci et al.,2002; Barbieri et al.,2006].

We also focused on occupational exposures to several chemotherapeutic drugs including cyclophosphamide, and concluded the precautionary measures we took were adequate to prevent occupational exposures [Ikeda et al.,2007; Maeda et al.,2010].

In this paper, because a progress of chemotherapy requires more versatile monitoring, we developed a multicomponent analysis method of chemotherapeutic drugs, and assessed the levels of environmental contaminations involved in preparation of chemotherapeutic drugs. Anthracycline drugs were light sensitive and were absorbed on glass containers [Lachatre et al.,2000] and vincalkaloid drugs were absorbed on some materials of tubes [Van Tellingen et al.,1991], we selected black Eppendorf tubes for stock solutions and working solutions, and light-blocking polypropylene tubes through extraction.

We prepare chemotherapeutic drugs in three different ways; (i) prepare drugs for outpatients on the BSCs equipped on a separated area, maintained constant a negative pressure, in hospital pharmacy; (ii) prepare drugs for inpatients on the BSCs equipped on a separated area in hospital pharmacy; (iii) prepare drugs for inpatients required special care (such as pretreatment for hematopoietic stem cell transplantation) on the BSCs equipped at the corner of the nurse station in a biological clean ward. We focused on environment of preparation for outpatients, because numbers of drugs were prescribed for outpatients and fast preparations were needed.

Our multicomponent analysis method had sufficient sensitivities and had conveniences enough for regular monitoring. Lower limits of quantitation were $5 \mathrm{ng} /$ wipe for doxorubicin, epirubicin, ifosfamide, cyclophosphamide, irinotecan and paclitaxel, 10 ng/wipe for docetaxel, and $100 \mathrm{ng} /$ wipe for vindesine, vincristine and vinblastine, respectively.

In the environmental assessments, vindesine, vincrisitine, vinblastine, epirubicin and irinotecan were not detected. Although doxorubicin, cyclophosphamide, docetaxel and paclitaxel were occasionally detected in the surfaces of the BSCs, frequencies and amounts of drugs detected were low levels in the surfaces of the working tables inside a separated area and outside one.

Inhalation and dermal penetration were presumed to be the main routes of occupational exposures. Several researchers [McDevitt et al.,1993; Sessink et al.,1994; Minoia et al.,1998] compared the urinary cyclophosphamide excretion levels and concentrations of cyclophosphamide in air during preparation of drugs. They concluded that the amounts of cyclophosphamide inhaled were much lower than amounts of cyclophsphamide excreted in urine, and that inhalation was not the main route of exposures resulting in high levels of cyclophosphamide. Fransman [Fransman et al.,2004, 2005] reported that dermal exposure predominantly occurred on the hands and sporadically on the forehead and forearms, and he mentioned that greater than $90 \%$ exposures were prevented by using latex gloves at the time of preparations. These reports showed that dermal exposures occurred on the hands 
were the main route of internal exposures. Thus, routine monitoring of unexpected environmental contaminations is very useful for preventing occupational exposures.

\section{Conclusion}

We developed a multicomponent analysis method of ten major chemotherapeutic drugs, and assessed the levels of environmental contaminations involved in preparation of chemotherapeutic drugs. We revealed that environmental contaminations outside BSCs were at low levels, and concluded that adequate precautionary measures and improved awareness regarding handling of chemotherapeutic drugs could reduce the risk of occupational exposures.

\section{References}

Anderson, D., Bishop, J. B., Garner, R. C., Ostrosky-Wegman, P., \& Selby, P. B. (1995). Cyclophosphamide: review of its mutagenicity for an assessment of potential germ cell risks. Mutation Research, Vol. 330, No. 1-2, pp. 115-181, ISSN 0027-5107

Barbieri, A., Sabatini, L., Indiveri, P., Bonfiglioli, R., Lodi, V., \& Violante, F. S. (2006). Simultaneous determination of low levels of methotrexate and cyclophosphamide in human urine by micro liquid chromatography/electrospray ionization tandem mass spectrometry. Rapid Communications in Mass Spectrometry, Vol. 20, No. 12, pp. 1889-1893, ISSN 0951-4198

Burgaz, S., Karahalil, B., Bayrak, P., Taskin, L., Yavuzaslan, F., Bokesoy, I., Anzion, R. B., Bos, R. P., \& Platin, N. (1999). Urinary cyclophosphamide excretion and micronuclei frequencies in peripheral lymphocytes and in exfoliated buccal epithelial cells of nurses handling antineoplastics. Mutation Research, Vol. 439, No. 1, pp. 97-104, ISSN 0027-5107

Connor, T. H., Shults, M., \& Fraser, M. P. (2000). Determination of the vaporization of solutions of mutagenic antineoplastic agents at 23 and 37 degrees $\mathrm{C}$ using a desiccator technique. Mutation Research, Vol. 470, No. 1, pp. 85-92, ISSN 0027-5107

Ensslin, A. S., Stoll, Y., Pethran, A., Pfaller, A., Rommelt, H., \& Fruhmann, G. (1994). Biological monitoring of cyclophosphamide and ifosfamide in urine of hospital personnel occupationally exposed to cytostatic drugs. Occupational and Environmental Medicine, Vol. 51, No. 4, pp. 229-233, ISSN 1351-0711

Falck, K., Grohn, P., Sorsa, M., Vainio, H., Heinonen, E., \& Holsti, L. R. (1979). Mutagenicity in urine of nurses handling cytostatic drugs. Lancet, Vol. 1, No. 8128, pp. 1250-1251, ISSN 0140-6736

Fransman, W., Vermeulen, R., \& Kromhout, H. (2004). Occupational dermal exposure to cyclophosphamide in Dutch hospitals: a pilot study. Annals of Occupational Hygiene, Vol. 48, No. 3, pp. 237-244, ISSN 0003-4878

Fransman, W., Vermeulen, R., \& Kromhout, H. (2005). Dermal exposure to cyclophosphamide in hospitals during preparation, nursing and cleaning activities. International Archives of Occupational and Environmental Health, Vol. 78, No. 5, pp. 403-412, ISSN 0340-0131

Goolsby, T. V., \& Lombardo, F. A. (2006). Extravasation of chemotherapeutic agents: prevention and treatment. Seminars in Oncology, Vol. 33, No. 1, pp. 139-143, ISSN 0093-7754 
Hedmer, M., Tinnerberg, H., Axmon, A., \& Jonsson, B. A. (2008). Environmental and biological monitoring of antineoplastic drugs in four workplaces in a Swedish hospital. International Archives of Occupational and Environmental Health, Vol. 81, No. 7, pp. 899-911, ISSN 0340-0131

Hirst, M., Tse, S., Mills, D. G., Levin, L., \& White, D. F. (1984). Occupational exposure to cyclophosphamide. Lancet, Vol. 1, No. 8370, pp. 186-188, ISSN 0140-6736

IARC (1981). Monographs on the Evaluation of the Carcinogenic Risk of Chemicals to Humans: Some Antineoplastic and Immunosuppressive Agents, Cyclophosphamide, International Agency for Research on Cancer, Lyon, France

Ikeda, K., Yagi, Y., Takegami, M., Lu, Y., Morimoto, K., \& Kurokawa, N. (2007). Efforts to ensure safety of hospital pharmacy personnel occupationally exposed to antineoplastic drugs during a preparation task. Hospital pharmacy (Philadelphia, PA), Vol. 42, No. 3, pp. 209-218, ISSN 0018-5787

Jakab, M. G., Major, J., \& Tompa, A. (2001). Follow-up genotoxicological monitoring of nurses handling antineoplastic drugs. Journal of Toxicology and Environmental Health, Part A, Vol. 62, No. 5, pp. 307-318, ISSN 1528-7394

Kasuba, V., Rozgaj, R., \& Garaj-Vrhovac, V. (1999). Analysis of sister chromatid exchange and micronuclei in peripheral blood lymphocytes of nurses handling cytostatic drugs. Journal of Applied Toxicology, Vol. 19, No. 6, pp. 401-404, ISSN 0260-437X

Kopjar, N., \& Garaj-Vrhovac, V. (2001). Application of the alkaline comet assay in human biomonitoring for genotoxicity: a study on Croatian medical personnel handling antineoplastic drugs. Mutagenesis, Vol. 16, No. 1, pp. 71-78, ISSN 0267-8357

Lachatre, F., Marquet, P., Ragot, S., Gaulier, J. M., Cardot, P., \& Dupuy, J. L. (2000). Simultaneous determination of four anthracyclines and three metabolites in human serum by liquid chromatography-electrospray mass spectrometry. Journal of Chromatography B, Vol. 738, No. 2, pp. 281-291, ISSN 1387-2273

Lanza, A., Robustelli della Cuna, F. S., Zibera, C., Pedrazzoli, P., \& Robustelli della Cuna, G. (1999). Somatic mutations at the T-cell antigen receptor in antineoplastic drugexposed populations: comparison with sister chromatid exchange frequency. International Archives of Occupational and Environmental Health, Vol. 72, No. 5, pp. 315-322, ISSN 0340-0131

Larson, R. R., Khazaeli, M. B., \& Dillon, H. K. (2003). Development of an HPLC method for simultaneous analysis of five antineoplastic agents. Applied Occupational and Environmental Hygiene, Vol. 18, No. 2, pp. 109-119, ISSN 1047-322X

Lissalde, S., Mazzella, N., Fauvelle, V., Delmas, F., Mazellier, P., \& Legube, B. (2011). Liquid chromatography coupled with tandem mass spectrometry method for thirty-three pesticides in natural water and comparison of performance between classical solid phase extraction and passive sampling approaches. Journal of Chromatography A, Vol. 1218, No. 11, pp. 1492-1502, ISSN 0021-9673

Maeda, S., Miyawaki, K., Matsumoto, S., Oishi, M., Miwa, Y., \& Kurokawa, N. (2010). Evaluation of environmental contaminations and occupational exposures involved in preparation of chemotherapeutic drugs. Yakugaku Zasshi Journal of the Pharmaceutical Society of Japan, Vol. 130, No. 6, pp. 903-910, ISSN 0031-6903

McDevitt, J. J., Lees, P. S., \& McDiarmid, M. A. (1993). Exposure of hospital pharmacists and nurses to antineoplastic agents. Journal of Occupational Medicine, Vol. 35, No. 1, pp. 57-60, ISSN 0096-1736 
Miao, L., Cai, W., \& Shao, X. (2011). Rapid analysis of multicomponent pesticide mixture by GC-MS with the aid of chemometric resolution. Talanta, Vol. 83, No. 4, pp. 12471253, ISSN 0039-9140

Minoia, C., Turci, R., Sottani, C., Schiavi, A., Perbellini, L., Angeleri, S., Draicchio, F., \& Apostoli, P. (1998). Application of high performance liquid chromatography/ tandem mass spectrometry in the environmental and biological monitoring of health care personnel occupationally exposed to cyclophosphamide and ifosfamide. Rapid Communications in Mass Spectrometry, Vol. 12, No. 20, pp. 14851493, ISSN 0951-4198

Nabeshima, T. S., Toru., Sugiura, S., Tanimura, M., Nakao, M., Nakanishi, H., \& Kato, K. (2008). Guidelines of an aseptically preparation and of antineoplastic drugs preparation (in Japanese). Journal of Japanese Society of Hospital Pharmacists, Vol. 44, No. 1, pp. 18-20, ISSN 1341-8815

NIOSH (2004). Preventing Occupational Exposure to Antineoplastic and Other Hazardous Drugs in Health Care Settings, The National Institute for Occupational Safety and Health, Atlanta, USA

Nussbaumer, S., Fleury-Souverain, S., Antinori, P., Sadeghipour, F., Hochstrasser, D. F., Bonnabry, P., Veuthey, J. L., \& Geiser, L. (2010). Simultaneous quantification of ten cytotoxic drugs by a validated LC-ESI-MS/MS method. Analytical and Bioanalytical Chemistry, Vol. 398, No. 7-8, pp. 3033-3042, ISSN 1618-2642

Pethran, A., Schierl, R., Hauff, K., Grimm, C. H., Boos, K. S., \& Nowak, D. (2003). Uptake of antineoplastic agents in pharmacy and hospital personnel. Part I: monitoring of urinary concentrations. International Archives of Occupational and Environmental Health, Vol. 76, No. 1, pp. 5-10, ISSN 0340-0131

Roth, S., Norppa, H., Jarventaus, H., Kyyronen, P., Ahonen, M., Lehtomaki, J., Sainio, H., \& Sorsa, M. (1994). Analysis of chromosomal aberrations, sister-chromatid exchanges and micronuclei in peripheral lymphocytes of pharmacists before and after working with cytostatic drugs. Mutation Research, Vol. 325, No. 4, pp. 157-162, ISSN 0027-5107

Sabatini, L., Barbieri, A., Tosi, M., \& Violante, F. S. (2005). A new high-performance liquid chromatographic/electrospray ionization tandem mass spectrometric method for the simultaneous determination of cyclophosphamide, methotrexate and 5fluorouracil as markers of surface contamination for occupational exposure monitoring. Journal of Mass Spectrometry, Vol. 40, No. 5, pp. 669-674, ISSN 1076-5174

Sebok, A., Vasanits-Zsigrai, A., Helenkar, A., Zaray, G., \& Molnar-Perl, I. (2009). Multiresidue analysis of pollutants as their trimethylsilyl derivatives, by gas chromatography-mass spectrometry. Journal of Chromatography A, Vol. 1216, No. 12, pp. 2288-2301, ISSN 0021-9673

Sessink, P. J., Boer, K. A., Scheefhals, A. P., Anzion, R. B., \& Bos, R. P. (1992). Occupational exposure to antineoplastic agents at several departments in a hospital. Environmental contamination and excretion of cyclophosphamide and ifosfamide in urine of exposed workers. International Archives of Occupational and Environmental Health, Vol. 64, No. 2, pp. 105-112, ISSN 0340-0131

Sessink, P. J., Van de Kerkhof, M. C., Anzion, R. B., Noordhoek, J., \& Bos, R. P. (1994). Environmental contamination and assessment of exposure to antineoplastic agents by determination of cyclophosphamide in urine of exposed pharmacy technicians: 
is skin absorption an important exposure route? Archives of Environmental Health, Vol. 49, No. 3, pp. 165-169, ISSN 0003-9896

Sessink, P. J., Kroese, E. D., van Kranen, H. J., \& Bos, R. P. (1995). Cancer risk assessment for health care workers occupationally exposed to cyclophosphamide. International Archives of Occupational and Environmental Health, Vol. 67, No. 5, pp. 317-323, ISSN 0340-0131

Skoczynska, E., Korytar, P., \& De Boer, J. (2008). Maximizing chromatographic information from environmental extracts by GCxGC-ToF-MS. Environmental Science and Technology, Vol. 42, No. 17, pp. 6611-6618, ISSN 0013-936X

Sottani, C., Turci, R., Schierl, R., Gaggeri, R., Barbieri, A., Violante, F. S., \& Minoia, C. (2007). Simultaneous determination of gemcitabine, taxol, cyclophosphamide and ifosfamide in wipe samples by high-performance liquid chromatography/tandem mass spectrometry: protocol of validation and uncertainty of measurement. Rapid Communications in Mass Spectrometry, Vol. 21, No. 7, pp. 1289-1296, ISSN 0951-4198

Sottani, C., Rinaldi, P., Leoni, E., Poggi, G., Teragni, C., Delmonte, A., \& Minoia, C. (2008). Simultaneous determination of cyclophosphamide, ifosfamide, doxorubicin, epirubicin and daunorubicin in human urine using high-performance liquid chromatography/electrospray ionization tandem mass spectrometry: bioanalytical method validation. Rapid Communications in Mass Spectrometry, Vol. 22, No. 17, pp. 2645-2659, ISSN 0951-4198

Tomioka, K., \& Kumagai, S. (2005). Health risks of occupational exposure to anticancer (antineoplastic) drugs in health care workers (in Japanese). Sangyo Eiseigaku Zasshi, Vol. 47, No. 5, pp. 195-203, ISSN 1341-0725

Turci, R., Sottani, C., Ronchi, A., \& Minoia, C. (2002). Biological monitoring of hospital personnel occupationally exposed to antineoplastic agents. Toxicology Letters, Vol. 134, No. 1-3, pp. 57-64, ISSN 0378-4274

Van Tellingen, O., Beijnen, J. H., \& Nooyen, W. J. (1991). Analytical methods for the determination of vinca alkaloids in biological specimens: a survey of the literature. Journal of Pharmaceutical and Biomedical Analysis, Vol. 9, No. 10-12, pp. 1077-1082, ISSN 0731-7085

Yoshida, J., Tei, G., Mochizuki, C., Masu, Y., Koda, S., \& Kumagai, S. (2009). Use of a closed system device to reduce occupational contamination and exposure to antineoplastic drugs in the hospital work environment. Annals of Occupational Hygiene, Vol. 53, No. 2, pp. 153-160, ISSN 1475-3162 


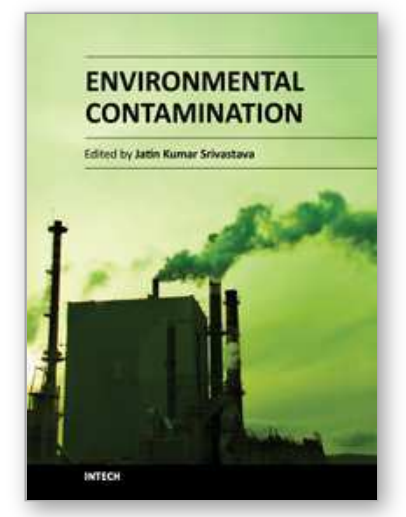

\author{
Environmental Contamination \\ Edited by Dr. Jatin Srivastava
}

ISBN 978-953-51-0120-8

Hard cover, 220 pages

Publisher InTech

Published online 29, February, 2012

Published in print edition February, 2012

Nature minimizes the hazards, while man maximizes them. This is not an assumption, but a basic idea of the findings of scientists from all over the world. The last two centuries have witnessed the indiscriminate development and overexploitation of natural resources by man causing alterations and impairment of our own environment. Environmental contamination is the result of the irrational use of resources at the wrong place and at the wrong time. Environmental contamination has changed the lifestyle of people virtually all over the world, and has reduced the extent of life on earth. Today, we are bound to compromises with such environmental conditions, which was not anticipated for the sustenance of humanity and other life forms. Let us find out the problem and its management within this book.

\title{
How to reference
}

In order to correctly reference this scholarly work, feel free to copy and paste the following:

Shinichiro Maeda, Masako Oishi, Yoshihiro Miwa and Nobuo Kurokawa (2012). Environmental Contaminations and Occupational Exposures Involved in Preparation of Chemotherapeutic Drugs, Environmental Contamination, Dr. Jatin Srivastava (Ed.), ISBN: 978-953-51-0120-8, InTech, Available from: http://www.intechopen.com/books/environmental-contamination/environmental-contaminations-andoccupational-exposures-involved-in-preparation-of-chemotherapeutic-

\section{INTECH}

open science | open minds

\author{
InTech Europe \\ University Campus STeP Ri \\ Slavka Krautzeka 83/A \\ 51000 Rijeka, Croatia \\ Phone: +385 (51) 770447 \\ Fax: +385 (51) 686166 \\ www.intechopen.com
}

\author{
InTech China \\ Unit 405, Office Block, Hotel Equatorial Shanghai \\ No.65, Yan An Road (West), Shanghai, 200040, China \\ 中国上海市延安西路65号上海国际贵都大饭店办公楼405单元 \\ Phone: +86-21-62489820 \\ Fax: +86-21-62489821
}


(C) 2012 The Author(s). Licensee IntechOpen. This is an open access article distributed under the terms of the Creative Commons Attribution 3.0 License, which permits unrestricted use, distribution, and reproduction in any medium, provided the original work is properly cited. 